\section{Making ESRO Ship-shape}

The European Space Research Organization is putting its house in order in preparation for the Third European Space Conference, which will take place in Bonn in June. The European Space Conference deals with the political aspects of a co-ordinated European space policy, and meets at least once a year at ministerial level. The previous meeting, at which Mr John Stonehouse, Minister of State for Technology, was Britain's principal representative, was held in Rome in July last year.

One of the outcomes of the Rome conference was that no new projects could be initiated by ESRO before the Bonn meeting, a decision expressing some dissatisfaction with the administrative and economic structure of ESRO. The new director-general of ESRO, Professor Hermann Bondi, who succeeded Professor Pierre Auger in November last year, sees as his main task the problem of getting ESRO into trim ready for the Bonn meeting. This involves the implementation of the findings of a report on the organization's structure, internal procedures and methods of work, prepared by a group of experts under the chairmanship of Mr. J. H. Bannier, a former chairman of the Council of CERN, the European nuclear research organization. The conclusions of the Bannier report included some reorganization of the managerial structure of ESRO, and the recommendation that the Council of ESRO should devote a greater proportion of its time to defining the policy and objectives of the organization. Professor Bondi is hoping that the reorganization at present under way will persuade the Bonn conference to lift the ban imposed last year.

Projects already in progress are not affected by the standstill. Three ESRO satellites are expected to be launched during 1968, and there is an extensive programme of small rocket launchings planned. A second attempt to launch the satellite ESRO.2 will be made in April-- the first attempt failed. because the third and fourth stages of the Scout launching rocket, fired from Vandenburg range in California, did not function. Although ESRO-2 was not placed in orbit, it transmitted signals up to eight minutes after the launch, an encouraging sign that the satellite itself was working correctly.

ESRO-1 will also be launched by a Scout rocket, probably in early October, followed in November by the launching of HEOS-A by a Delta rocket. HEOS-A will be ESRO's first satellite to be placed in a highly eccentric orbit, its purpose being the investiga. tion of atomic particles and magnetic fields outside the magnetosphere.

Sounding rocket firings in 1968 will be based on ESRO's range at Kiruna, in northern Sweden. Most of the launchings will be from Kiruna, except four payloads which for scientific reasons cannot be launched at high latitudes. These experiments involve astro. nomical investigations which may be affected by auroras and studies of geophysical phenomena only observed at middle latitudes, and will be flown from a range in Sardinia.

The diverse experiments planned for the Kiruna flights include studies of auroral disturbances in the ionosphere, investigations of micrometeorites, and measurements of galactic X-rays. Perhaps the most interesting launching from the range in Sardinia will be an experiment to study the X-ray spectrum of the Sun, using a Skylark rocket fitted with a device that keeps the rocket pointing at the Sun.

Although the Rome conference recognized that a merger of the three European space organizationsESRO, ELDO and CETS (the European Conference for Telecommunications by Satellites) - was not yet possible, a unified European space organization is likely to emerge in the future. This problem will also be receiving much of Professor Bondi's attention in 1968.

\section{Threat to French High Energy Physics from our Paris Correspondent}

THERE are unaccustomed signs of discontent at present among the 600 French physicists who are specialists in high energy physics and who are preoccupied by the uncertainty hanging over the future of their subject. There are petitions circulating and collecting signatures, animated meetings in laboratories and a good deal of lobbying along the corridors of power. The publication next month of the report of the Consultative Committee for Research can doubtless only aggravate this state of affairs.

The twelve "wise men" (two doctors, two economists, a mathematician, a chemist, three physicists, a scientific agriculturist, a business man and a sociologist) who make up this committee responsible for advising the government departments on scientific policy were asked a year ago to furnish recommendations on the future of high energy physics. One of the important issues in this study was obviously the decision relating to the plan for a $45 \mathrm{GeV}$ proton accelerator. The committee has just presented to the government a document of some 30 pages summarizing the results of its work. This report analyses the present situation and is most complimentary about the excellence of the French teams, which have, in the committee's view, assured for themselves an enviable position, particularly in CERN.

This expression of satisfaction for the men themselves is accompanied by rather more stringent comments on material resources. "French physicists, who for some time have been at an advantage by comparison with their European colleagues, now find themselves making use of more old-fashioned and generally less powerful machines." After such a preamble, the report's conclusions are extremely surprising. The committee judges, in effect, that high energy physics has for a long time benefited from a priority which, if continued, would compromise the progress of other subjects, and therefore urges that the increases of expenditure and in the number of research workers between now and 1980 should be curbed. The spending on fundamental research should be generally cut from $17 \cdot 3$ per cent to 15 per cent-indeed, even to 13 per cent of the research and development budget during this period -and the ceiling for expenditure on particle physics should be pegged at 5,400 million francs instead of the 6,645 million francs which was thought to be the necessary minimum sum by the working party on large accelerators. The rate of growth in the number of physicists would be limited to 3 per cent (those most concerned with the matter were asking for 5 per cent).

On the question of the $45 \mathrm{GeV}$ machine, the wise men did not make any categorical statements: they 
are in favour of building it if it does not imperil the budgetary restrictions outlined here, which makes it something of a problem. On the other hand, the committee does emphasize the urgent need for drastic reorganization, bringing together again all the activity at present dispersed and, above all, recovering the work now under the wing of the Atomic Energy Com. mission.

The physicists are not unanimous in their reaction to these points, which cannot in any case be examined seriously from the point of view of France alone. The uncertainty hanging over the $300 \mathrm{GeV}$ of CERN, the ambiguous attitude of Germany which had envisaged a Franco-German $45 \mathrm{GeV}$ and which, tired of Paris beating about the bush, is now talking of building such an accelerator itself, has decidedly complicated the issue. However, whatever the position of the French particle physicists on the opportunity for building the $45 \mathrm{GeV}$ machine and on the choice of technical solutions, they would, at all events, like the government to make a quick and clear decision. They are also surprised, and apparently justifiably so, that the question of priority from which their subject has benefited is being called into question at this point, particularly so because the committee of wise men states that the effort has been a "paying one". A change in policy will surely compromise the results so far achieved-these have already for some time been a bit precarious because of the antiquated equipment -without necessarily making certain of marked progress in other fields of research. However, "a fine sprinkling of funds" has so often been a characteristic of French research and development programmes.

\section{Machine Minding}

Next month the British Computer Society will have to decide whether to go ahead with the plan to turn itself into a professional body. The plan, put forward in June 1967, proposes that the society should become the learned institution for computer scientists, establishing four grades of membership-student, associate, member and fellow. Ultimately, admission to the society will be controlled by examination, and the society aims to do for the computer scientists what the engineering institutions have done for the engineers.

Not all the present members of the society are enthusiastic about the plan. Some say that computer science is still too young and diffuse a discipline to be easily examinable, others that experience will always be worth much more than paper qualifications. Many of the existing members of the society are computer users rather than scientists, and one member of the society compared the present efforts with a hypothetical situation in which all those who used television sets had to become qualified as electronic engineers. For all this, the plan is almost certain to be approved at the extraordinary general mecting at the end of March.

The simple reason for this is the remarkable way in which the membership of the society has increased since the plan was announced. Although the reference books list the membership of the society as 3,000 , it has now reached a figure of $18,000,10,000$ of whom have joined since the new plans for the society became public knowledge. Although the secretary of the society, Mr J. G. Mackarness, sees this as evidence of general approval for the society's plans, others see it as a rush to get into the society before the examinations are established. Existing associate or ordinary members will be exempt from the examinations if they have more than seven years experience-if not, they will have to serve an apprenticeship as subscribing members until the seven years are up, when they will become members without cxamination. Existing student members will only have to take examinations if they are under twenty-one on May 1 this year.

In fact, the society had a problem in pitching the terms at exactly the right level. If all existing members had to take examinations - as properly they should if the society is to become as respectable as the engineering institutions-then new applicants would have been discouraged. The society admits that its reserves are "tiny", and hence needed to increase its subscription income substantially. This has been done most successfully, but possibly at the cost of losing credibility as a learned society. Moreover, subscription income will increase substantially again soon, for the rate for

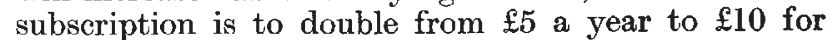
members - a figure "very much in line with other professional bodies" according to $\mathrm{Mr}$ Mackarness, particularly as publications of the society are sent free to members. When the decision is taken at the end of March, only a fraction of the membership will be able to be present, but the rest-including those who have joined in the last year-will be able to vote by proxy.

\section{Too Many Institutions}

UNDETERRED by the refusal of the Institution of Heating and Ventilating Engineers to contemplate a merger with his institution, Mr H. G. Conway, president of the Institution of Mechanical Engineers, had another try on February 16. He was invited to speak at the annual dinner of another engineering institution, the Institution of Plant Engineers, and made use of the occasion to offer the plant engineers a merger with his own institution. Mr Conway was anxious not to be cast in the role of an empire builder-"My own institution has no territorial ambitions or illusions of grandeur. We presidents come and go. . . We speak of our profession as our conscience may dictate. Some of us feel that if a few of our institutions could get together we would have benefited the engineering profession as a whole".

The terms offered for the merger are generous, and very similar to those turned down by the Institution of Heating and Ventilating Engineers (see Nature, $21 \%, 498 ; 1968$ ). The plant engineers would form a divisional section with a good deal of autonomy. They could elect their own president and council, hold their own meetings and publish a journal. The alternatives, Mr Conway suggested, were either to apply for status as a chartered engineering bodywhich he thought unlikely to succeed, as there was a general view that the present proliferation of institutions is wrong-or become a technician body and aspire to chartered technician status.

The Institution of Plant Engineers is taking the offer quietly. It says only that it has "taken note" of Mr Conway's suggestion, which will be "carefully considered by the council of the institution", and a further statement will be made in due course. The 